\title{
Linkage Effects of Rural Non-Farm Income Diversification on Poverty Reduction among Farm Households in Southeast, Nigeria
}

\author{
Odoh, N. E. ${ }^{1}$, Nwibo, S. U. ${ }^{2}$ \\ Department of Agricultural Economics, Management and Extension, Ebonyi State University, P.M.B 053, Abakaliki, Nigeria
}

\begin{abstract}
The incidence of poverty in rural communities of Nigeria like many other African countries is very severe and breaking the incidence requires diversification into non-farm activities which no documented empirical records seems to exist in Southeast Nigeria. In addressing the problem, the study measured the poverty status of the rural farm households; determined the effect of non-farm income diversification on the poverty reduction level of the rural farm households; and determined the linkage effect of non-farm income activities of the rural farm households on total household income. The study employed a combination of multistage and purposive sampling techniques in the selection of 360 rural farm households. Foster Greer Thorbecke (FGT) poverty index was used to realise objective (i) which allow for the quantitative measurement of poverty status, while objectives (ii) and (iii) were realised using simple regression analysis. The result revealed that $\mathbf{5 0 . 6}$ percent of the rural farm households were actually poor while about 33.4 percent were far from the poverty line. Again, the severity of poverty among the poor farmers in the Southeast, Nigeria was 11.3 percent. Again, the Herfindal Index revealed that diversification has resulted to $66 \%$ increase in rural farm household income. Similarly, nonfarm income has a positive effect on poverty reduction level of farm households in Southeast, Nigeria as it accounts for $62 \%$ of the total household income. Based on the findings, the study recommended for total diversification of the rural farm households so as increase their income and break the vicious circle of poverty.
\end{abstract}

Keywords: Non-farm income, poverty line, rural, diversification, households

\section{Introduction}

The non-farm sector is a major contributor to employment and income generation of rural households. In Nigeria, nonfarm contributes up to $63 \%$ of household income (Fabusoro et al., 2010). IFAD (2009) posited that non-farm income is important to the rural poor as, farm income obtained by poorer households is barely enough to provide family needs due to landlessness or because they own/lease little farm land. Second, agriculture employment is seasonal by nature, so the poor take non-farm sources as income supplementation. Third, non-farm activities favour the poorer households because they require little capital and generate more employment per unit of capital than do agricultural activities. Fourth, by providing employment for vulnerable groups such as women, youths, small farmers and poor landless people, it can help to reduce income inequality".

The non-farm sector plays several roles in the development of the rural sector. Lanjouw and Lanjouw (2001) state four roles of non-farm sector as: "First, the non-farm sector produces lower quality goods and services which are often used by the poor; good performance of this sector indirectly contributes to lowering prices to the poor households. Second, it is a major source of employment to the poor who, due to ownership of small land or high cost of land, cannot depend on farming alone. Third, through expansion into non-farm activities, it also provides a way of spreading income throughout the seasons, for households with limited access to micro-finance sources. Fourth, good performance of this sector can sustain agricultural labour market, increase local wages, thereby reducing rural poverty".
Non-farm income is often a source of expansion and investment in agriculture and other householdse capital investment. Also farm income and savings serve as sources of funds for investment in non-farm activities. The notion of livelihood diversity is based on a system that considers the activities of the rural poor people as being determined by the kind of assets, including social, human, financial, natural and physical capital (Carney, 1998). He maintained that employment, households ${ }^{c e}$ income sources, survival and coping strategies reflect, ,rural ${ }^{\text {ee }}$ assets and are further influenced by the policies and institutions that surround them and other broader economic factors. These factors include markets, inflation, trade, infrastructure, urban, public policies, financial capital, land, education, social, environmental issues, etc. It is believed by the World Bank, IFAD, DFID and other international agencies that promoting the non-farm sector as an alternative means of income and employment could serve as one of the ways to reduce inequalities and poverty in the rural areas.

According to Barrett et al. (2001), diversification is widely regarded as a form of self-insurance in which people exchange some foregone expected earnings for reduced income variability achieved by choosing a kind of assets and activities that have low or negative correlation of incomes. This view is also shared by many other authors such as Reardon et al. (1992) and (2000). Fabusoro et al. (2010) defined livelihood diversification as attempts by people to pursue new means in order to increase household income and reduce risks, which differ sharply by the degree of freedom of choice, whether to diversify or not and the reversibility of the outcome. Ellis (1998) states that livelihood diversification describes a process by which households participate in a wide variety of income activities and social support capabilities as survival strategies for risk 


\section{International Journal of Science and Research (IJSR) \\ ISSN (Online): 2319-7064 \\ Index Copernicus Value (2013): 6.14 | Impact Factor (2015): 6.391}

reduction and overcoming income instability caused by seasonality and low production output in order to improve their welfare.

Haggblade et al. (2002) states that highly diverse and heterogeneous, RNFE offers opportunities for the rural poor households as well as the rich. These authors stressed that poor people frequently seek economic refuge through distress diversification into low-skill non-farm activities, while the rich ones participate in a dynamic portfolio of more sophisticated, high-productivity and skill-intensive businesses. In the past, governments and policy makers tended to view the African rural economy as one that wholly depended only on farming alone, but there is evidence from several livelihood researches suggesting that rural households in Africa are increasingly depending on combinations of activities.

There have been numerous empirical studies on the link between economic growth and poverty. The advent of the Millennium Development Goals (MDGs) and Poverty Reduction Strategy Papers (PRSPs) have underlined the need to establish the relationship between growth and poverty. In rural areas, it is evident that the most effective means to increase income and reduce poverty is to increase the productivity of local activities which households depend on for their livelihoods. Promoting rural enterprises is vital for economic growth and poverty reduction. Local industries and small businesses generate employment and innovation and can contribute to structural transformation and the expansion of agriculture.

It has been shown by many authors that the rural economies of most regions depend on good performance of both agricultural and non-agricultural activities (Lanjouw 1999, Lanjouw and Lanjouw 2001). Haggblade et al. (2002) maintains that widespread economic liberalization during the 1990s has opened up rural non-farm sector as never before, creating new opportunities and new threats. This diverse collection of seasonal trading, family-based and large-scale agro-processing, manufacturing and service activities plays a major role in sustaining rural households, in servicing a growing and modern agriculture, and in supplying local consumer goods and services. The emergence of new businesses generates employment and innovation and can contribute to structural transformation in rural areas.

Poverty in Nigeria like many other African countries is very severe in rural communities, where up to $80 \%$ of the population live below the poverty line due to lack of infrastructure and social services (IFAD, 2009). National surveys in Nigeria have consistently shown poverty as a rural phenomenon. Surveys for the past 16 years by the National Bureau of Statistics (NBS) of Nigeria show that poverty was most widespread in rural areas, rising from $28.3 \%$ in 1980 to $69.3 \%$ in 1992 and declining to $63.3 \%$ in 2004 (NBS, 2007). It has also been reported that SubSaharan African countries have the highest poverty rates with nearly $60 \%$ of the working population living below US\$1.25 per day (Onyeiwu and Liu, 2011).

Despite the high poverty rates in rural communities, the rural sector provides the bulk of overall employment in Nigeria.
The farm sector employs about two-thirds of the countryes total labour force and provides a livelihood for about $90 \%$ of the rural population (IFAD 2009a). Of the total working population of 52,326,923 in 2006, agriculture and other rural activities employed a total of $30,682,234$ which is more than half of the working population (NBS, 2007). The percentage contribution of agriculture and other rural activities to overall economic activity in 2006 was $62 \%$ and it was nearly half $(42.2 \%)$ of the contribution to national GDP in 2007 (NBS, 2008). The national GDP growth rate in 2006 was $6.0 \%$ of which at about $3.0 \%$, agriculture contributed almost half of the GDP growth rate (NBS, 2007). Despite its contribution to GDP, this sector exhibits high unemployment and poverty rates. The relative poverty trend by occupation of head of household showed that those engaged in agriculture was $31.4 \%(1980), 53.5 \%$ (1985) and $67 \%$ in 2004 (NBS 2007).

Subsistence farming dominates income activities in Nigerian rural communities. According to Fabusoro et al. (2010), these rural farmers are resource poor and cultivate between 0.1 and 2.0 hectares of land. The crucial role of agriculture can be gauged from the fact that small-scale farmers produce about $90 \%$ of Nigeriaes food crops and are main drivers of the rural economy (IFAD 2009). Haggblade et al. (2002) maintains that the declining farm income in African rural villages drives households to undertake non-farm activities as alternative or supplementary sources of income, so as to reduce fluctuations in income from agricultural activities. In places where landlessness prevails, the non-farm sector provides important economic alternatives for the rural poor households.

Meanwhile, a lot of empirical studies have been documented on non-farm income diversification across economies. Such studies include Poverty and Income Diversification among Households in Rural Nigeria: A Gender Analysis of Livelihood Patterns (Oluwatayo, 2009); income diversification of rural households in Central Sulawesi, Indonesia (Schwarze and Zeller, 2005); determinants and effects of income diversification amongst farm households in Burkina Faso (Reardon, Delgado, and Malton, 1992); but there seems to exist dearth of empirical studies on the linkage effects of rural non-farm income diversification on poverty reduction among farm households in Southeast Nigeria. In view of the problem, the study was guided on the following objectives:

1) Determine the poverty status of the rural farm households

2) Determine the effect of non-farm income diversification on the poverty reduction level of the rural farm households; and

3) Determine the linkage effect of non-farm income activities of the rural farm households on total household income.

\section{Methodology}

The study was conducted in the Southeast, Nigeria which comprised of five States, namely; Abia, Anambra, Ebonyi, Enugu, and Imo States. The area which is mainly of Igbo extraction has total population of 16.4 million people. With an approximated land mass of 58,214.7 square kilometres, 


\section{International Journal of Science and Research (IJSR) \\ ISSN (Online): 2319-7064}

Index Copernicus Value (2013): 6.14 | Impact Factor (2015): 6.391

the area lies between longitude $6^{0} 50^{I}$ and $8^{0} 30^{I}$ E latitude $4^{0}$ $30^{I}$ and $7^{O} 5^{I} \mathrm{~N}$. The area shares boundaries with CrossRiver State in the east, in the west by Delta and River States, in the north by Benue and Kogi States, and in the south by Akwa-Ibom State. Inhabitants of the area are predominantly smallholder farmers growing mainly arable crops like; yam, cassava, maize rice, cocoyam, potato, and few plantation crops like palm tree and cashew. In order to complement income from agriculture most of the farmers engage in livelihood diversification in off-farm.

The study employed a combination of multistage and purposive sampling techniques were employed in the selection of respondents in the study area. The choice of purposive sampling technique was to select States that are more agrarian and to avoid picking States that are contiguous to each other. The stages involved in the selection are:

Stage 1: This involved the purposive selection of three States from the five States of Southeast Nigeria. The states include Abia, Anambra and Ebonyi.

Stage 2: $\quad$ From the three purposively selected States, three agricultural zones each were purposively selected to give a total of nine (9) agricultural zones.

Stage 3: From the nine (9) agricultural zones that were selected, two Blocks were randomly selected to give a total of 18 Blocks.

Stage 4: From each of the randomly selected eighteen (18) Blocks, two (2) circles were randomly selected to give a total of thirty (36) circles.

Stage 5: From the randomly selected 36 circles, ten (10) farming households each were randomly selected. Thus, a total of three hundred and sixty (360) farming households were used as the sample size for the study. Meanwhile, the sample frame was determined from ADP list of all the registered farming households in the States that were sampled.

A preliminary survey was carried out to determine the location of the farming communities in the selected areas. From the selected farm households, data were collected primarily using structured questionnaire and interview schedule. Data on each household were provided by the head of the household (male-headed or female-headed).

The study inferential statistics to achieve its objectives. Specifically, Foster Greer Thorbecke (FGT) poverty index to realise objective which allow for the quantitative measurement of poverty status (i). The FGT measure is defined as

$\mathrm{P}=\frac{1}{N} \sum_{i-1}^{q}\left(\frac{\mathrm{z}-\mathrm{y}_{\mathrm{i}}}{\mathrm{z}}\right)^{\alpha}$

Where, $\mathrm{Pi}$ is the poverty index; $N_{i}$ is the size of the ith households; $\alpha$ is poverty aversion parameter value $0,1,2$;

$y_{i}$ is household per capita expenditure; $q$ is the number of poor households (poverty line); $Z$ is the absolute poverty line value (threshold value of income). Objectives (ii) and (iii) were realised using OLS multiple regression analysis.

\section{Results and Discussion}

This section presents the results and discussion of data analysis of three hundred and sixty (360) rural farm households based on the specific objectives. The results were presented under the following headings: poverty index of the rural farm households; effect of non-farm income diversification on the poverty reduction level of the rural farm households; and the linkage effect of non-farm income activities of the rural farm households on total household income.

\section{Rural farm household poverty status}

The level of poverty among the rural farm households was determined using Foster-Greer-Thorbecke (FGT). The FGT model seeks to allow the estimation of the headcount, the poverty incidence and the poverty gap for a given sample. To achieve this, three poverty indicators were used as rule of thumb: $\alpha=0$ implies prevalence or concern for poverty which defines the percentage of the farm households that fall below the poverty line, $\alpha=1$ implies poverty depth uniform concern for poverty among the farm households or the amount by which the poor falls short of the poverty line; $\alpha=2$ indicates the severity of poverty which defines the distinction between the poor and the poorest.

From the analysis, it was observed that the poverty measure given by $P_{0 i}$ which defines the incidence of poverty was 0.506. This implies that 50.6 percent of the rural farmers were actually poor. Hence, it ran contrary to National Bureau of Statistics (NBS, 2006) that reported the poverty level of rural residence of Southeast, Nigeria in 2004 was 26.7 percent. Meanwhile, the poverty incidence of the poor households in Ogun State according to Adekoya (2014) on the State s poverty survey was 78.1 percent which was fairly higher than that of the Southeast, Nigeria and that of the Southwest, Nigeria which was reported to be $76.4 \%$. At the poverty measure of $\alpha=1$ which conveys the poverty depth among the rural farm households, the $P_{1 i}$ value for the rural farmers was 0.334. This implies that the rural farm households in Southeast, Nigeria are by 33.4 percent far from the poverty line. Therefore, for them to get out of poverty, they required about $\$ 2825.64$ additional income. Finally, the poverty severity index $\left(P_{2 i}\right)$ which was measured at $\alpha=2$, and that which defines the distinction between the poor and the poorest (inequality among the poor) was 0.113 . This therefore conveys that the severity of poverty among the poor farmers in the Southeast, Nigeria was 11.3 percent. Hence, the result shows a marginal gap between the poor and the poorest farm households. It is justified as most of the households are into peasantry farming and little diversification options. This finding corroborates Olubanjo, Akinleye, and Soremekun (2000) who reported that the severity of poverty among the poor farmers of Ogun State was $21.5 \%$. It is equally consistent with Adewunmi (2013) who reported that the severity of poverty rural farm households in Southwest, Nigeria was about $17.3 \%$ 


\section{International Journal of Science and Research (IJSR) \\ ISSN (Online): 2319-7064 \\ Index Copernicus Value (2013): 6.14 | Impact Factor (2015): 6.391}

Table 1: Poverty level of rural farm households using Foster-Greer-Thorbecke (FGT)

\begin{tabular}{|c|c|c|}
\hline FGT Measures & Poverty indices (Pi) & Southeast \\
\hline$\alpha=0$ & $\mathrm{P}_{0 \mathrm{i}}$ & 0.506 \\
\hline$\alpha=1$ & $\mathrm{P}_{1 \mathrm{i}}$ & 0.334 \\
\hline$\alpha=2$ & $\mathrm{P}_{2 \mathrm{i}}$ & 0.112 \\
\hline
\end{tabular}

Poverty line $=\mathrm{N} 8,460$

Mean Household per capita expenditure per month $=$ N12,653.57

\section{Household Income Generation}

A combination of both farm and non-farm activities determine the income status of a farm household. Analysis shown in Table 2 indicate that though the income level of the household is made-up of the two components, there exist a disparity in the income earned from farm activities and that earned from diversified activities by the farm households for the past five years. From the analysis it was observed that households that diversified from farm earned higher income than those that did not diversify. A closer look at the trends of income earned showed a steady increase in the income level of the diversified households. Furthermore, the Herfindal Index value which is above 0.60 or $60 \%$ gave a good impression of the fact that significant difference exist between farm income and non-farm income. Meanwhile, within the period under review, Herfindal Index revealed that diversification has resulted to $66 \%$ increase in rural farm household income. This finding justified that of Haggblade, Hazell and Reardon (2007) who reported that diversification into off-farm activities has been an important component of livelihood strategies as with the potential of increasing share of off-farm income in total household income. The finding also is in consonance with Reardon et al. (1998) who posited that non-farm activities contribute up to $42 \%$ of total farm household income in Africa $40 \%$ in Latin America and $32 \%$ in Asia.

Table 2: Estimated Mean Income from Farm and Non-farm Economic Activities for the Past Five Years (2009-2013)

\begin{tabular}{|c|c|c|c|c|}
\hline Year & Farm & Non-farm & Difference & $\begin{array}{c}\text { Herfindal } \\
\text { Index }\end{array}$ \\
\hline 2009 & 154205.5556 & 248747.2222 & 94541.667 & 0.62 \\
\hline 2010 & 184939.1111 & 331670.5556 & 146731.444 & 0.64 \\
\hline 2011 & 208081.6667 & 412621.1111 & 204539.445 & 0.66 \\
\hline 2012 & 231221.8889 & 546680.5333 & 315458.645 & 0.70 \\
\hline 2013 & 278641.9167 & 571096.1778 & 292454.261 & 0.67 \\
\hline Total & $1,057,090.139$ & $2,110,816$ & $1,053,725$ & - \\
\hline Mean & $211,418.027$ & $422,163.2$ & $210,745$. & 0.66 \\
\hline
\end{tabular}

Source: Household Survey Data 2014

\section{Effect of Non -Farm Income on the Poverty Reduction Level of Farm Households}

A very close look at the farming communities of Southeast Nigeria will evidently reveal the fact that agriculture alone cannot reduce rural poverty. Again, it has been hypothesized that non-farm income has no significant effect on the poverty reduction level of the farm households in Southeast Nigeria. However, analysis to of data collected reveals that the co-efficient of non farm income was positive and statistically significant at $1 \%(P=0.01)$. This implies that non-farm income has a positive effect on poverty reduction level of farm households in Southeast, Nigeria. Further analysis of the result shows that the marginal effect was not substantial as non-farm income contributes about $0.3 \%$ in poverty reduction of the farm households. Meanwhile, the magnitude of the effect was explained by the coefficient of determination $\mathrm{R}^{2}(0.724)$ which was relatively very substantial. To further justify the finding, a hypothesis test was conducted and result revealed that non-farm income has significant effect on poverty reduction level of the households at $1 \%$ level. There non-farm employment has the potential of unlocking the vicious circle of rural poverty as indicated in Table 3. These findings justified the view of Oluwatayo (2009) who posited that growth in the income of rural -households are closely related to their income diversification portfolio. Hence, corroborating UNECA (2005) report that despite Nigeriaes abundant agricultural resources and oil wealth, poverty is still rampant among the farming communities. The report therefore suggested that the most effective means of reducing the rural poverty is to increase productivity of the farm and diversification into non-farm activities. It is on the basis of this that Awoyemi (2004) inferred that farming is fast taking a minor share of peasant's households ${ }^{e e}$ income, since rural livelihood strategies have become increasingly dependent on income generated from engagement in off-farm activities.

Table 3: Effect of Non-Farm Income on the Poverty Reduction Level of Farm Households

\begin{tabular}{|c|c|c|c|c|c|}
\hline Variable & Parameter & $\begin{array}{c}\text { Co- } \\
\text { efficient }\end{array}$ & $\begin{array}{c}\text { Standard } \\
\text { Error }\end{array}$ & T-value & Significance \\
\hline Constant & $\beta \mathrm{o}$ & 528.443 & 37.548 & 14.075 & .000 \\
\hline $\begin{array}{c}\text { Non-Farm } \\
\text { Income }\end{array}$ & $\beta 1$ & 0.003 & 0.000 & 30.670 & .000 \\
\hline
\end{tabular}

$\mathrm{R}$

$=\quad .724$

Durbin - Watson $=\quad 1.973$

Linkage Effect of Non-Farm Income on Total Annual Income of the Rural Households.

Farm-Non-Farm linkages - is a concept used to explain the relationship between farm and non-farm sectors in the rural economy. Nwaru (2005) in their findings stated that when agricultural productivity grows, rural household income increases and the additional household demand caused by agricultural expansion has a very high multiplier effect across the rest of the economy, particularly in closed economies, which is in practice the case of many developing rural economies due to high transaction costs. Farm/nonfarm linkages seek to find out whether expansion of one sector is hindering the existence or performance of the other sector by competing for source inputs and capital.

The result of the regression analysis shows that the coefficient of non-farm income was positive and statistically significant. This expenditure linkage occurs when income obtained from one of the two sectors is used to purchase the outputs of the other. The underlying principle is that growth in the non-farm sector induces the expansion of expenditure on farm output. Investment linkages describe this relationship which exists where investment of capital generated in one of the sectors is used in the expansion of the other (IFAD, 2009b). The result of this finding is in agreement with that of (Haggblade et al., 2002; Rearden et al., 2007) who in the different studies suggested that non- 


\section{International Journal of Science and Research (IJSR) \\ ISSN (Online): 2319-7064 \\ Index Copernicus Value (2013): 6.14 | Impact Factor (2015): 6.391}

farm sector have the potential to contribute to growth and rural development. These authors are strongly of the opinion that rural households in developing countries are finding it difficult to engage profitably in agriculture and have been diversifying into non-farm activities. IFAD (2009b, 2011 and 2012) suggest that this accounts for the high rate of poverty in rural communities that solely depend on agriculture as primary sources of livelihood. This implies that non-farm income is often a source of reinvestment in non-farm agriculture. Similarly farm income also serves as source of funds for investment in non-farm businesses. This study found that non-farm income accounts for $62 \%$ of the total household income as confirmed by the value of coefficient of determination $\left(\mathrm{R}^{2}\right)$. It follows that non-farm income provides a higher proportion of capital for investment than farm income.

Final regression equation is stated

$\mathrm{Y}=5.307+1.052 \mathrm{E}-006$

$(0.026)^{*}(0.000)^{*}$

Table 4: Linkage Effect of Non-Farm Income on Total Annual Income of the Rural Households.

\begin{tabular}{|c|c|c|c|c|}
\hline Variable & Parameter & Co-efficient & $\begin{array}{c}\text { Std } \\
\text { Error }\end{array}$ & T-value \\
\hline Constant & Bo & 5.307 & 0.026 & $201.520^{*}$ \\
\hline Non-Farm Income & $\beta 1$ & $1.052 \mathrm{E}-006$ & 0.0000 & $12.708^{*}$ \\
\hline Coefficient of multiplier & $\mathrm{Me}$ & 0.004169 & - & - \\
\hline $\mathrm{R}^{2}$ & & 0.615 & & \\
\hline$\overline{\mathrm{R}^{2}}$ & & 0.613 & & \\
\hline Durbin-Watson $=$ & & 1.703 & & \\
\hline
\end{tabular}

\section{Conclusion}

With the poverty incidence of 50.6 percent in Southeast, Nigeria rural farm households diversified their income portfolio into non-agricultural activities in which it was observed that non-farm income has a positive effect on poverty reduction in the area. Again, it is concluded that non-farm income contributes significantly to the total household income having accounts for $62 \%$ of the total household income in Southeast, Nigeria.

Based on the findings of the study therefore recommended for total diversification of the rural farm households so as increase their income and break the vicious circle of poverty.

\section{References}

[1] Adekoya, O. A. (2014). Analysis of Farm Household Poverty Status in Ogun State, Nigeria. Asian Economic and Financial Review, 4(3): 325 - 430.

[2] Adewunmi, O.I. (2013). Poverty Profile of Rural Farm Households in Southwest, Nigeria. Agronomie Africaine, 25(3): 309 -319.

[3] Awoyemi, T. T. (2004). Rural Non-Farm Incomes and Poverty Reduction in Nigeria. A Report Submitted to AERC, Nairobi, Kenya.

[4] Barrett, C.B., Reardon T. and Webb P. 2001. NonAgricultural Income Diversification and Household Livelihood Strategies in Rural Africa: Concepts, Dynamics and Policy Implications. Food Policy, 26(4): 315-331.
[5] Carney, D. (1998). Implementing the Sustainable Rural Livelihood Approach. In D. Carney (ed.) Sustainable Rural Livelihoods: What Contribution Can We Make? London: Department of International Development. Papers Presented at the Department for International Development's Natural Resources Advisers Conference. July 1998.

[6] Ellis, F. (1998). Household Strategies and Rural Livelihood Diversification. Journal of Development Studies, 35(1): 1-38.

[7] Fabusoro, E., A. M. Omotayo, S. O. Apantaku and Okuneye, P. A. (2010). Forms and Determinants of Rural Livelihoods Diversification in Ogun State, Nigeria. Journal of Sustainable Agriculture, 34(4): 417 $-438$.

[8] Foster, J. E., Greeer, J., and Thorbeck, E. (1984). A Class of Decomposable Poverty Measures. Econometrica, 52(1) - 761 - 766 .

[9] Haggblade, S., Hazell, B. and Reardan, T. (2007). Transforming the Rural Non-farm Economy, Opportunities and Threats in the Developing World. Baltimore, John Hopkins University Press.

[10] Haggblade, S., Hazell, P. and Reardon, T. (2002). Strategies for stimulating poverty-alleviating growth in the rural non-farm economy in developing countries. EPTD Discussion Paper, No. 92, Rural Development Department. The World Bank, Washington, DC.

[11] IFAD (2009a). Federal Republic of Nigeria, Country Programme Evaluation. September 2009, Report No. 1959-NG, International Fund for Agricultural Development.

[12]IFAD (2009b). Rural Enterprise and Poverty Reduction. Asia and the Pacific Division. International Fund for Agricultural Development.

[13] Lanjouw, J.O. and Lanjouw, P. (2001). The rural nonfarm sector: issues and evidence from developing countries. Agricultural Economics, 26 (1): 1 - 23.

[14]Lanjouw, P. (1999). Rural Non-Agricultural Employment and Poverty in Ecuador. Economic Development and Cultural Change, 48(1): 91-122.

[15] National Bureau of Statistics (2005). Socioeconomic Survey on Nigeria, Abuja.

[16] National Bureau of Statistics (2007). Social Statistics in Nigeria, Federal Republic of Nigeria, NBS. http://www.nigerianstat.gov.ng

[17] National Bureau of Statistics (2008). Poverty Profile for Nigeria. National Bureau of Statistics, Abuja.

[18] Nwaru J.C. (2005). Determinants of Farm and Off-farm Incomes and Savings of Food Crop Farmers in Imo State, Nigeria: Implications for Poverty Alleviation. Nigeria Agricultural Journal, (36): 26-42.

[19] Olubanjo, O., Akinleye, S., and Soemekun, W. (2007). Poverty Determinants among Farmers in Ogun State. Agricultural Journal, 2(2): 257 - 280.

[20] Oluwatayo, I.B. (2009). Poverty and Income Diversification among Households in Rural Nigeria: A Gender Analysis of Livelihood Patterns. A Paper Presented at the 2nd Instituto de Estudos Sociais e Económicos (IESE) Conference on „Dynamics of Poverty and Patterns of Economic Accumulation in Mozambique , Maputo, Mozambique, 22-23 April, 2009. 


\section{International Journal of Science and Research (IJSR) \\ ISSN (Online): 2319-7064}

Index Copernicus Value (2013): 6.14 | Impact Factor (2015): 6.391

[21] Onyeiwu, S. and Liu, J. (2011). Determinants of Income Poverty in Rural Africa: Empirical Evidence from Kenya and Nigeria. Paper Presented at the African Economic Conference, Addis Ababa, October 26-28, 2011.

[22] Reardon, T., Cruz, M.E., Berdegué, J. (1998). Los pobres en el desarrollo del empleo rural no agrícola en América Latina: paradojas y desafíos. Invited Plenary Paper at the Tercer Simposio Latinoamericano de Investigatión y Extensión en Sistemas Agropecuarios, Lima, 19-21 August.

[23] Reardon, T., Delgado, C. and Malton, P. (1992). Determinants and effects of Income Diversification amongst farm Households in Burkina Faso. Journal of Development Studies, 28(2): 264-296.

[24] Schwarze, S. and Zeller, M. (2005). Income diversification of rural households in Central Sulawesi, Indonesia. Quarterly Journal of International Agriculture, 44(1): 61-73.

[25]UNECA (2005). Economic Report on Africa: Meeting the Challenge of Unemployment and Poverty in Africa. Addis Ababa.

[26] UNECA (2007). Survey of Economic and Social Condition in Africa. 